University of Nebraska - Lincoln

DigitalCommons@University of Nebraska - Lincoln

Agronomy \& Horticulture -- Faculty Publications

Agronomy and Horticulture Department

2-1-1995

\title{
Quantifying Developmental Morphology of Perennial Grasses
}

\author{
K. J. Moore \\ lowa State University, kjmoore@iastate.edu \\ Lowell E. Moser \\ University of Nebraska-Lincoln, Imoser1@unl.edu
}

Follow this and additional works at: https://digitalcommons.unl.edu/agronomyfacpub

Part of the Plant Sciences Commons

Moore, K. J. and Moser, Lowell E., "Quantifying Developmental Morphology of Perennial Grasses" (1995). Agronomy \& Horticulture -- Faculty Publications. 81.

https://digitalcommons.unl.edu/agronomyfacpub/81

This Article is brought to you for free and open access by the Agronomy and Horticulture Department at DigitalCommons@University of Nebraska - Lincoln. It has been accepted for inclusion in Agronomy \& Horticulture -Faculty Publications by an authorized administrator of DigitalCommons@University of Nebraska - Lincoln. 


\title{
Quantifying Developmental Morphology of Perennial Grasses
}

\author{
K. J. Moore* and L. E. Moser
}

\begin{abstract}
Perennial forage grasses can be viewed as modular organisms. The phytomer is usually considered the basic unit of the grass plant and consists of a leaf blade and sheath, the internode, the node, and the associated axillary bud below the point of sheath attachment. The tiller is a collection of phytomers differentiated from a single apical meristem. The grass plant is a group of tillers that ultimately arise from a single zygote and are of the same genotype. A grass sward is a population of individual plants, often genetically related, but usually of unique genotypes. The developmental morphology of perennial grass swards is dynamic and is a function of the spatial and temporal distribution of growth stages within the population of tillers comprising the sward. Management practices are applied to forages at the sward level. Systems for quantifying developmental morphology of perennial grasses that are to be used for management purposes must be applicable at the sward, or population, level. The phyllochron concept, which is widely used in studies of cereals, has been employed in only a limited number of studies on forage management. Numerical indices have been used successfully to quantify grass morphology, but have some inherent limitations when used for predictive purposes. The principles of population ecology, particularly plant demography, provide a framework for studying the developmental morphology of perennial grass populations and can be used in conjunction with numerical indices to describe tiller populations.
\end{abstract}

$\mathrm{D}$ VELOPMENTAL MORPHOLOGY of perennial grasses is an important consideration in the application and timing of forage management practices. Leaf appearance (phyllochron) during seedling development has been used to evaluate stand establishment and is strongly related to root development within a given grass species (Moser et al., 1993). Leaf development in tillers of perennial grasses is useful for determining the timing of management practices such as defoliation, burning, fertilization, and growth regulator and pesticide application (Moore et al., 1991). The quantity and quality of forage grasses is affected greatly by plant morphology. Decisions regarding grazing and harvest management should be made on the basis of plant development (Frank et al., 1993). The appearance and expansion of leaves following a period of dormancy or defoliation of perennial grasses is necessary to achieve a positive $C$ balance to support further growth and development (Davies, 1988). Physiological responses to defoliation and future growth potential are largely a function of developmental morphology and are an important consideration in managing forage grasses (Parsons, 1988; Waller et al., 1985).

Despite the importance of grass developmental morphology to understanding and making forage management decisions, there is no generally agreed upon method for describing and quantifying morphological development as there is for most annual cereal crops (Haun,

K.J. Moore, Dep. Agronomy, lowa State Univ.; and L.E. Moser, Dep. Agronomy, Univ. of Nebraska. Joint contribution of the Iowa and Nebraska Agric. Exp. Stn. Received 11 Mar. 1994. *Corresponding author (kjmoore @iastate.edu).

Published in Crop Sci. 35:37-43 (1995).
1973; Large, 1954; Ritchie et al., 1989; Simmons et al., 1985; Vanderlip, 1979). Perennial grasses used for forage differ from annual cereals in ways that make quantifying their developmental morphology inherently more difficult. They typically are cross-pollinated and so each population represents a collection of related genotypes rather than a single genotype. Consequently, there is typically more variation in developmental morphology within a population of perennial forage grasses than would be encountered in annual cereal crops. Systems for quantifying the morphological development of grasses for the purpose of making management decisions need to consider this variation in developmental morphology within a population.

The phyllochron concept, which is widely used in studies of cereals, has been employed in only a limited number of studies on forage management. Numerical indices have been used successfully to quantify grass morphology but have some inherent limitations. The objectives of this paper are to (i) provide an overview of perennial grass morphology with emphasis on those aspects that make it difficult to quantify and (ii) to describe methodology developed for this purpose.

\section{PERENNIAL GRASS MORPHOLOGY Modular Organization of Grasses}

Morphology of the grass plant can be conceptualized as a hierarchial arrangement of structural subunits or modules (Table 1; Briske, 1991; White, 1984). The perennial grass plant is a collection of tillers that arise from a single crown and are of the same genotype as the primary tiller. Each tiller is composed of a series of phytomers differentiated from a common apical meristem (Langer, 1979; Robson et al., 1988). Although there is debate as to what constitutes a phytomer (Clark and Fisher, 1987), it is usually defined as a leaf blade and sheath, the internode, the node, and the associated axillary bud below the point of sheath attachment (Briske, 1991; Fig. 1). The phytomer is specific to the Poaceae but is closely related to the more broadly applied term phyton (White, 1984).

The architecture of a grass tiller is determined by size, number, and spatial arrangement of phytomers (Briske, 1991). Tillers are formed from buds located in leaf axils of the lower internodes of the primary stem or another tiller (Fig. 2). A grass plant is a collection of tillers that arise from a single primary tiller or crown (Skinner and Nelson, 1994). Tillers of a grass plant, therefore, develop from the same zygote and are of the same genotype. The architecture of an individual grass plant is determined by the morphology and spatial arrangement of tillers (Briske, 1991).

A single plant may represent several generations of tillers (Fig. 3). Each axillary bud has the potential of

Abbreviations: GDD, growing degree days; MSC, mean stage count. 
Table 1. Hierarchical organization of a perennial grass population.

\begin{tabular}{lll}
\hline Component & Synonym & \multicolumn{1}{c}{ Composition } \\
\hline Phytomer & Metamer & 1 leaf blade and sheath, \\
& & 1 internode, 1 node, \\
& and 1 axillary bud \\
Tiller & Module & $n$ phytomers \\
Plant & Genet & $m$ tillers \\
Sward & Population & $l$ plants \\
\hline
\end{tabular}

forming a tiller. Tillers also arise from axillary buds of other tillers; and it is the ability of these buds to overwinter that allows these grasses to perennate (Jewiss, 1972). The developmental stage of tillers within the same plant can vary greatly; a single plant may have vegetative and reproductive tillers present at the same time (Moore et al., 1991).

After a rhizomatous grass population is established, differentiation of individual plants becomes impossible, so these grasses must be either evaluated as individual tillers or as a population of tillers. Cespitose grasses retain their individual plant identity longer, although with time, individual crowns may fragment and form genetically identical ramets. Even then, the new individual plants can be identified, whereas this is virtually impossible with rhizomatous or stoloniferous grasses.

A grass sward is a population of individual plants, often genetically related, but usually of unique genotypes. Most perennial forage grasses are open-pollinated, and therefore, each population represents a collection of related genotypes rather than a pure line. Because of this relationship, there is more variation in developmental morphology within a population of perennial forage grasses than would be encountered in an annual cereal. Management practices are applied to forages at the population or sward level. Systems for quantifying developmental morphology of perennial grasses that are to be used for management purposes must be applicable at the

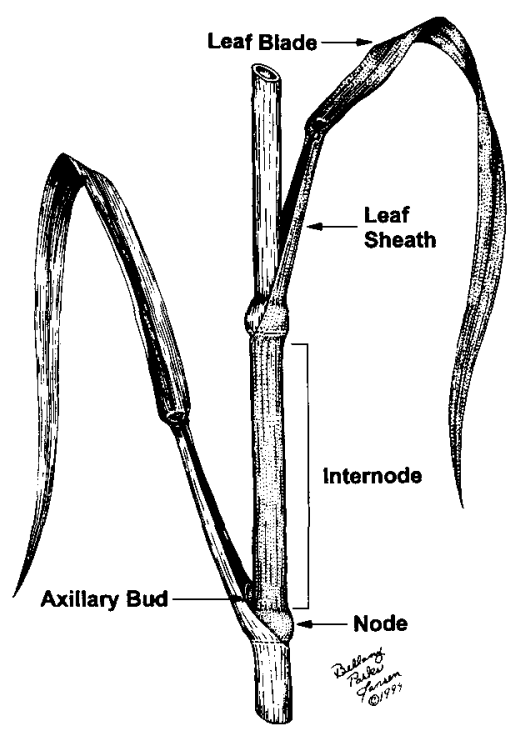

Fig. 1. Illustration of the grass phytomer. The phytomer is the basic unit of the grass plant and consists of a leaf blade and sheath, the internode, the node, and the associated axillary bud below the point of sheath attachment.

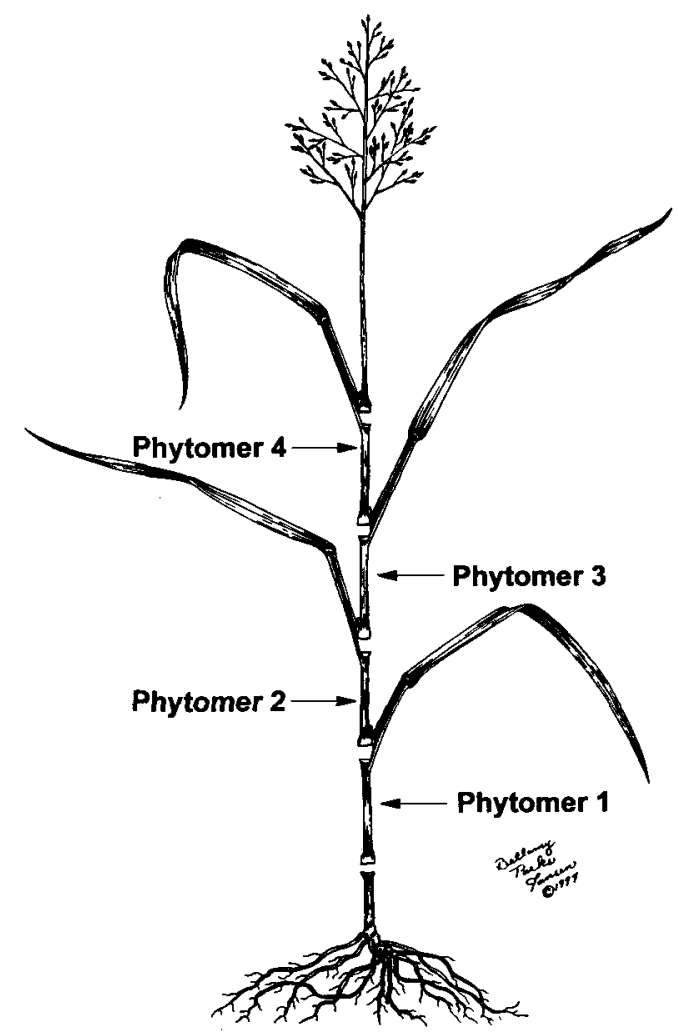

Fig. 2. Illustration of a grass plant showing developing tiller and arrangement of phytomers. A grass plant is a collection of tillers that arise from a single primary tiller or crown and are of the same genotype.

population level and consider the inherent variability in developmental morphology.

\section{Developmental Morphology}

The developmental morphology of perennial grass swards is dynamic, and the architecture of the canopy is continually changing. The architecture of the sward

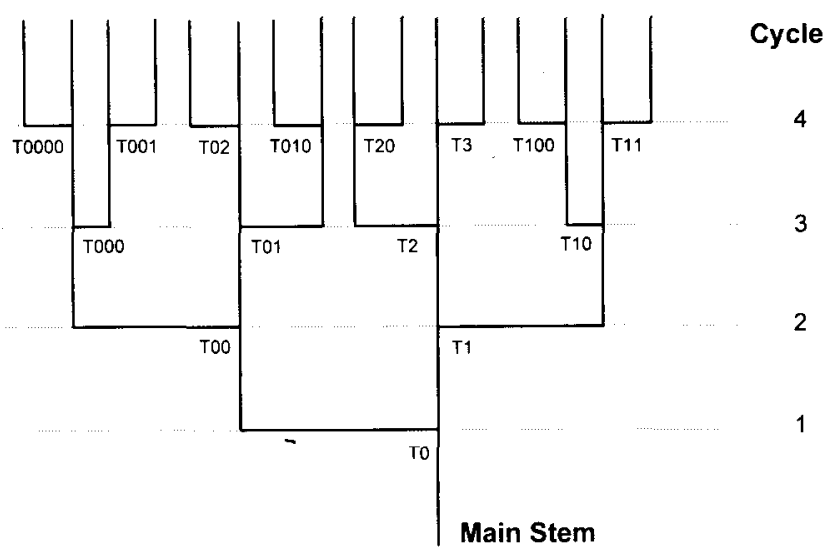

Fig. 3. Hierarchy of tiller development in perennial grasses. Tillers are formed from buds located in leaf axils of the lower internodes of the main stem, or another tiller. On the main stem, tillers formed from buds in the axils of the coleoptile and first three leaves are shown as T0 through T3. Subsequent generations are noted by the tiller and node from which they arise (After Skinner and Nelson, 1992). 
is a function of tiller morphology at various growth stages and the distribution of growth stages within the population of tillers comprising the sward. However, the development of individual grass tillers proceeds through a sequence of developmental events that is relatively common among genera with some notable exceptions.

The ontogeny of a perennial grass tiller can be divided into four primary growth periods: vegetative, elongation, reproductive, and seed ripening (Moore et al., 1991). Vegetative development begins with the emergence of the prophyll and encompasses the period during which leaf growth and development occurs. During vegetative development, stem internodes are differentiated but do not elongate. The vegetative growth period is characterized by the successive appearance of leaves. The interval of time between the appearance of suceessive leaves, the phyllochron, is relatively constant during the vegetative development of a tiller (Langer, 1979) but is influenced by environmental factors such as temperature, photoperiod, and light quality (Davies and Thomas, 1983; Casal et al., 1985). Once a critical leaf area has been established, the older and lowermost leaves often senesce at a rate nearly equal to the rate of new leaf appearance so that the number of leaves present on a tiller becomes relatively constant once leaf senescence begins to occur (Langer, 1979; Robson, 1982). As long as the tiller remains vegetative, the apical meristem is indeterminate and, theoretically, an infinite number of phyllochrons can occur. When spikelet primordia appear, there is no potential for further initiation of leaves and the shoot apex becomes determinate (Hyder, 1972; Langer, 1979).

Elongation is the period during which internodes elongate. This period is often referred to as jointing. When the tiller begins to elongate, usually in response to photoperiod, the internodes associated with the uppermost phytomers elongate in an acropetal manner. The lowermost internodes do not elongate and remain basal. These lower nodes and internodes together with those of associated tillers constitute the crown of the plant. The elongation period is sometimes referred to as transition because it represents the transition between vegetative and reproductive growth (Waller et al., 1985). As a result of elongation, the developing inflorescence exserts through the uppermost leaf sheath to form what is commonly referred to as boot stage.

The reproductive phase becomes obvious with the appearance of the first spikelets from the uppermost leaf sheath. The spikelet is the basic unit of the grass inflorescence (Clifford, 1987). It consists of one or more florets, depending upon species, enclosed within a pair of bracts called glumes. There are three basic types of inflorescences found in grasses based upon the manner in which spikelets are attached to the rachis, or axis, of the inflorescence. In a spike, the spikelets are sessile to the rachis, whereas in a raceme, the spikelets are attached to the rachis by a pedicel. The panicle is the most common type of grass inflorescence and is characterized by one to several orders of branching. Spikelets are borne on panicle branches, which are attached to the rachis by pedicels. Regardless of type, development of the grass inflorescence is determinate and occurs basipetally (Gould and Shaw, 1983) in most species. The extent of development of the inflorescence when it emerges varies with species. In some species, such as big bluestem (Andropogon gerardii Vitman) and indiangrass [Sorghastrum nutans (L.) Nash], anthesis can occur before the inflorescence is fully exserted. A single inflorescence will bear spikelets representing a range of maturities. Anthesis can occur during several days for a single inflorescence and in many species, occurs during certain daily time periods (Hovin, 1980; Burson, 1980).

Following anthesis and fertilization, the caryopses begin to develop. During this phase of development, the plant partitions nutrients into developing caryopses. The plant is said to have reached physiological maturity when the caryopsis has accumulated maximum dry matter. At this time, an abscission layer forms near the pedicel and prevents further accumulation of assimilates (McDonald et al., 1994, unpublished data).

\section{QUANTIFYING DEVELOPMENTAL MORPHOLOGY}

\section{Phyllochron Index}

As described elsewhere in this series of papers (Wilhelm and McMaster, 1995), the term phyllochron has several interpretations. It is often used as a synonym for the grass leaf. It is also used to describe specific morphological events related to leaf development, such as appearance of the blade or collar. More appropriately, it is used to describe the interval of time between two successive morphological events. Phyllochrons are often expressed in units of thermal time such as growing degree days (GDD) per phyllochron. In this later context, the phyllochron is related to the broadly applied plastochron index (Ford, 1982).

There has been only limited research on the use of the phyllochron in managing forage grasses. Frank et al. (1985) studied the phyllochron in four species; crested wheatgrass (Agropyron desertorum (Fischer ex Link) Schultes), western wheatgrass (Agropyron smithii Rydb.), intermediate wheatgrass [Thinopyrum intermedium (Host) Barkw. \& D.R. Dewey], and reed canarygrass (Phalaris arundinacea L.). Within each of these species, they evaluated two clones each of two cultivars for a total of four genotypes per species. They found that the relationship between GDD and phyllochrons developed was linear for all four species (Fig. 4). There were significant differences among species in the GDD required to achieve a given phyllochron, particularly later in development. Reed canarygrass developed the most leaves (8) and required the smallest number of GDD per phyllochron (84). Western wheatgrass represented the other extreme, requiring an average of 147 GDD per phyllochron. So although the relationship between the phyllochron and GDD was linear for all species, the slope (or phyllochron interval) was different. Based upon this and other work, Frank et al. (1993) have developed guidelines for grazing management for several native and introduced grasses using the phyllochron concept.

The concept of a standard unit of morphological time such as the phyllochron expressed in units of thermal time 


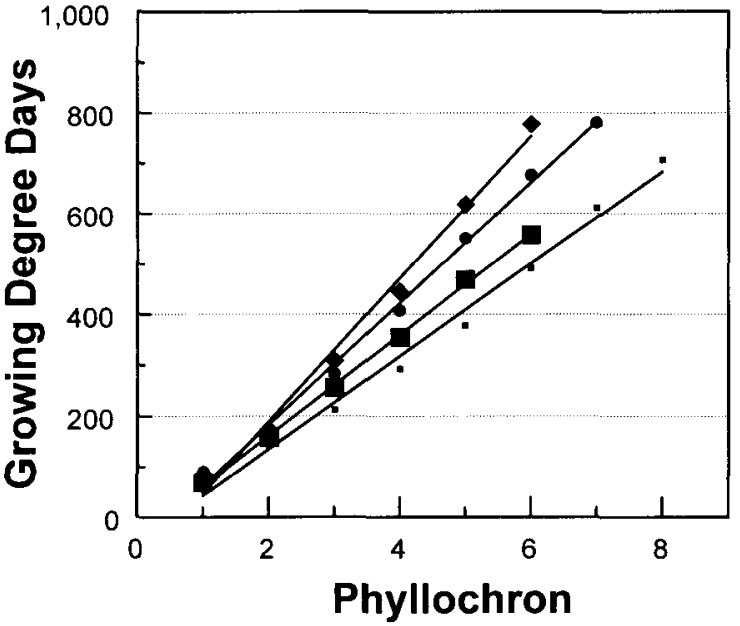

\begin{tabular}{|llc|}
\hline & \multicolumn{2}{c|}{ GDD / Phyllochron } \\
\hline - & Crested Wheatgrass & 104 \\
- & Intertern Wheatgrass & 147 \\
- & Reed Canarygrass & 125 \\
\hline
\end{tabular}

Fig. 4. Phyllochron development in four perennial grasses as a function of growing degree days. Data from Frank et al. (1985).

is appealing because it would enable forage producers to base management decisions on accumulated heat units. However, for this to be possible, the phyllochron interval for a species would have to be relatively consistent across a wide range of climatic and edaphic conditions. Although the phyllochron interval is relatively consistent for a given genotype within a given environment, there is genetic variation in the phyllochron interval among and within grass cultivars (Frank et al., 1985). There are also a number of environmental factors that influence the phyllochron interval including temperature, vernalization, photoperiod, light quality, and light intensity (Cao and Moss, 1994; Casal et al., 1985, 1986; Davies and Thomas, 1983). The phyllochron interval also varies during the ontogeny of the plant, generally increasing at later stages of vegetative development (Skinner and Nelson, 1992).

The phyllochron concept has not been widely applied in forage management studies. This is primarily because of the difficulty in its application at the population level. Another limitation of the phyllochron concept for forage management is that it is restricted to vegetative development. Although the vegetative phase encompasses many important events relevant to management of a grass sward, there are a number of management decisions, particularly with regard to utilization, that need to be made at later stages of maturity.

\section{Numerical Indices}

There are a number of numerical indices that have been developed for the purpose of quantifying morphological development of perennial grasses (Moore et al., 1991; Sanderson, 1992; Simon and Park, 1983; West, 1990). The phyllochron concept itself is in essence a numerical
Table 2. Primary and secondary growth stages as described by Moore et al. (1991) and their numerical indices and descriptions for staging growth and development of perennial grasses.

\begin{tabular}{lcl}
\hline Stage & \multicolumn{2}{c}{ Index $\dagger$} \\
\hline & \multicolumn{2}{c}{ Vegetative - leaf development } \\
Ve or Vo & 1.0 & Emergence of first leaf \\
V1 & $(1 / N)+0.9$ & First leaf collared \\
V2 & $(2 / N)+0.9$ & Second leaf collared \\
Vn & $(n / N)+0.9$ & $N^{\text {th }}$ leaf collared \\
& \multicolumn{2}{c}{ Elongation - stem elongation } \\
Eo & 2.0 & Onset of stem elongation \\
E1 & $(1 / N)+1.9$ & First node palpable/visible \\
E2 & $(2 / N)+1.9$ & Second node palpable/visible \\
En & $(n / N)+1.9$ & $N^{\text {th }}$ node palpable/visible \\
& \multicolumn{2}{c}{ Reproductive - floral development } \\
Ro & 3.0 & Boot stage \\
R1 & 3.1 & Inflorescence emergence/first spikelet visible \\
R2 & 3.3 & Spikelets fully emerged/peduncle not emerged \\
R3 & 3.5 & Inflorescence emerged/peduncle fully elongated \\
R4 & 3.7 & Anther emergence/anthesis \\
R5 & 3.9 & Post-anthesis/fertilization \\
& \multicolumn{3}{c}{ Seed development and ripening } \\
S0 & 4.0 & Caryopsis visible \\
S1 & 4.1 & Milk \\
S2 & 4.3 & Soft dough \\
S3 & 4.5 & Hard dough \\
S4 & 4.7 & Endosperm hard/physiological maturity \\
S5 & 4.9 & Endosperm dry/seed ripe \\
\hline
\end{tabular}

† Where $n$ equals the event number (number of leaves or nodes) and $N$ equals the number of events within the primary stage (total number of leaves or nodes developed). General formula is $P+(n / N)-0.1$; where $P$ equals primary stage number ( 1 or 2 for vegetative and elongation, respectively) and $n$ equals the event number. When $N>9$, the formula $P+0.9(n)$ $N$ ) should be used.

index that is limited to early vegetative development. Although the approach varies among these systems, they all share some common characteristics; each system has a defined series of morphological descriptors that have an associated numerical index.

The system developed by Simon and Park (1983) has probably been the most widely used in studies of forage grasses. Their system was based upon the one developed by Zadoks et al. (1974) for cereals with some modifications to account for developmental stages unique to perennial grasses. Many of the morphological descriptors in the Simon and Park system are ambiguous, requiring subjective judgements, and it is complex and generally difficult to apply in the field. Frank et al. (1993) have successfully employed the system used by Haun (1973) to quantify wheat (Triticum aestivum L.) development for quantifying the development of perennial grasses. The Haun system, however, applies only to leaf development through culm elongation and, therefore, its use is limited primarily to vegetative development.

Moore et al. (1991) developed a system for quantifying the developmental morphology of grasses designed to be used in forage and range management studies. Their system is based on the ontogeny of individual tillers, which is divided into the four primary growth stages: (i) vegetative, (ii) elongation, (iii) reproductive, and (iv) seed ripening (Table 2). Within each primary stage, substages are defined that correspond to specific morphological events. Each growth stage consists of a primary and secondary stage and has a numerical index associated with it that can be used for quantitative purposes. 
Numerical indices can be used to quantify the developmental morphology of a population of tillers by collecting a random sample of tillers and determining the stage of each tiller in the sample. The mean developmental stage can be calculated using the following equation:

$$
M S C=\frac{\sum_{i=0}^{\operatorname{Max}} \sum_{j=1}^{N_{i}} S_{i j}}{C}
$$

Where MSC $=$ mean stage count, $S_{i}=$ growth stage, $i=0$ to maximum growth stage, $N_{i}=$ number of tillers in stage $S_{i}, C=$ total number of tillers.

An example of quantifying developmental morphology using the indices described in Table 2 is presented in Fig. 5 in which the MSC of smooth bromegrass (Bromus inermis Leysser) and intermediate wheatgrass are plotted with respect to time. Both grasses were grown in plots at the University of Nebraska Agricultural Research and Development Center near Mead, Nebraska. Tillers were clipped from six randomly placed $0.09-\mathrm{m}^{2}$ quadrats for each species on the days indicated during the 1990 growing season. The morphological development of both species followed a similar growth function characteristic of temperate forage grasses. Both species had a similar MSC early in the growth period. However, smooth bromegrass began to mature earlier than intermediate wheatgrass and was about 1 wk ahead from Weeks 3 through 7 . After this time, development of smooth bromegrass began to level off and intermediate wheatgrass continued development and was equal to that of smooth bromegrass by $9 \mathrm{wk}$.

Within a grass population, there is generally significant variation in tiller morphology at any time during the growing season. The structure of the sward is a function of tiller architecture at various growth stages and the distribution of growth stages within a population of tillers. Frequency distributions for tiller populations of intermediate wheatgrass and big bluestem growing near Mead, NE, in midJune 1990 are presented in Fig. 6. Intermediate wheatgrass, a cool-season grass, was more mature at this date than big bluestem, a warm-season

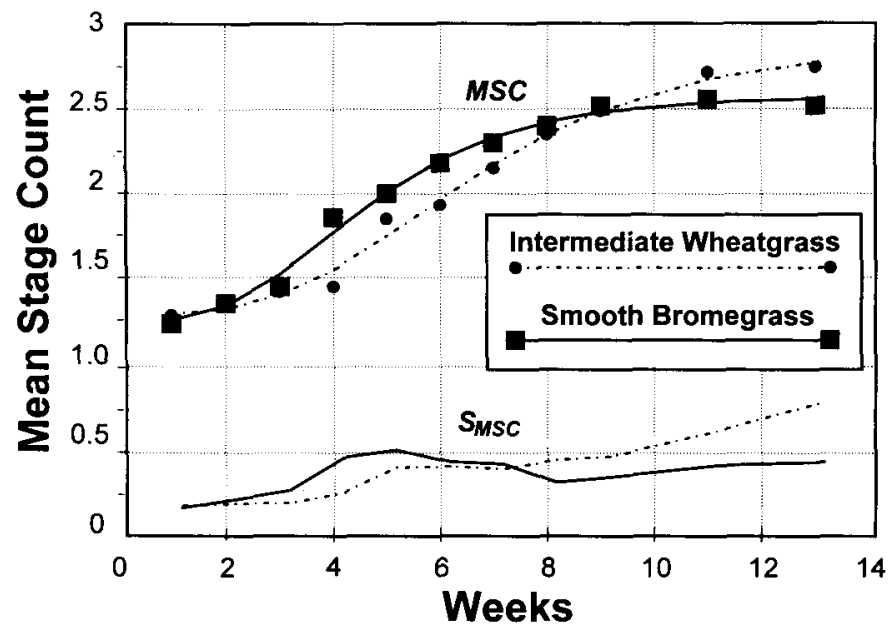

Fig. 5. Mean stage count (MSC) and its standard deviation ( $S_{\text {MSC) }}$ for smooth bromegrass and intermediate wheatgrass grown near Mead, NE, during the 1990 growing season. grass. Intermediate wheatgrass also had a wider range of developmental stages present at this date. The variation in developmental morphology within a tiller population may be of more importance in making some management decisions than the actual MSC.

An estimate of the variation about the MSC within a population of tillers can be calculated as the standard deviation of the mean stage by count (Moore et al., 1991):

$$
S_{\mathrm{MSC}}=\sqrt{\sum_{i=0}^{\operatorname{Max}} \frac{\left(S_{i}-\mathrm{MSC}\right)^{2} \times N_{i}}{C}}
$$

The $S_{\mathrm{MSC}}$ is useful for interpreting the variability in maturity that exists within a population of tillers. A small $S_{\mathrm{MSC}}$ indicates that most of the tillers within the population are of similar maturity and would be expected to have a maturity near the MSC. A large $S_{\text {MSC }}$ indicates that there is a wide range in maturity within the population. The bottom two lines in Fig. 5 represent the $S_{\text {MSc }}$ of smooth bromegrass and intermediate wheatgrass plotted with respect to time. Early in vegetative development, the $S_{\mathrm{MSC}}$ is low and similar between species. However, the $S_{\text {MSc }}$ increases with advancing maturity for both species and after $8 \mathrm{wk}$ there was more variation associated with the MSC of intermediate wheatgrass than for smooth bromegrass. It is interesting to compare the $S_{\mathrm{MSC}}$ at the point where the MSC lines of the two species intersect at 2.5 ; the $S_{\mathrm{MSc}}$ of wheatgrass is considerably greater, indicating that it contains greater variation in tiller maturity than smooth bromegrass. Even though the two populations have the same MSC at this point in time, they are much different in their morphological composition.

It is the variation in maturity among the tillers comprising a sward that limits the utility of numerical indices for making forage management decisions. The MSC can be useful for describing the developmental morphology

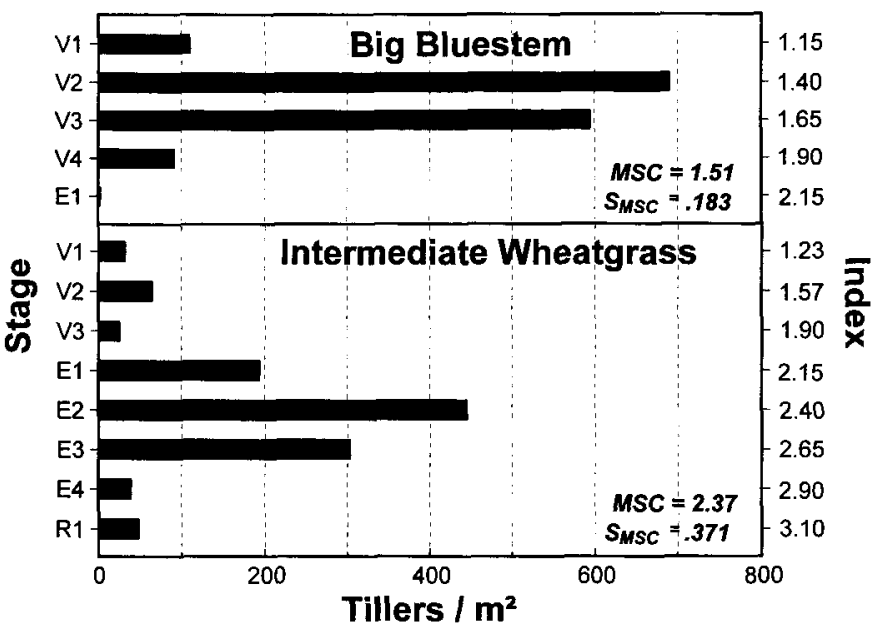

Fig. 6. Frequency distribution of growth stages, mean stage count (MSC), and the standard deviation of mean stage $\left(S_{\mathrm{MSc}}\right)$ for tiller populations collected from intermediate wheatgrass and big bluestem in midJune near Mead, NE. Growth stages are described in Table 2. (After Moore et al., 1991). 
of a sward particularly when an estimate of the variation about the MSC is provided. However, because there is a great deal of temporal and spatial variability in the morphological development of a sward, it is difficult to predict the MSC from one growing season to the next.

\section{Plant Demography}

A grass sward can be considered as a dynamic population of tillers (Marshall, 1987). At any time, the architecture of the sward is determined by the spatial distribution and morphology of the tillers comprising it (Briske, 1991). The structure of the tiller population varies with time reflecting seasonal changes in the developmental morphology of individual tillers (Fig. 7). One approach to describing the variation within grass populations that occurs with respect to time is through the application of the principles of plant demography. The fundamental theory of demography is that changes in a population of individuals can be described by accounting for births and deaths occurring within the population (Harper, 1980). Because grasses are modular organisms, the principles of demography can and have been applied at several levels in studies of population ecology (Harper, 1980). A grass plant itself can be considered a metapopulation constructed of repeated metamers (phytomers; White, 1984). By definition, a grass tiller is a module consisting of a series of metamers derived from a single apical meristem and a grass plant is a genet, a collection of modules having arisen from a single embryo (Table 1; White, 1979). However, from a practical perspective, a grass sward can be described most easily by the demography of its tiller population.

A demographic analysis of an intermediate wheatgrass tiller population is presented in Fig. 7 in which the number of tillers in each of the primary growth stages described earlier are plotted with respect to time. At the first four

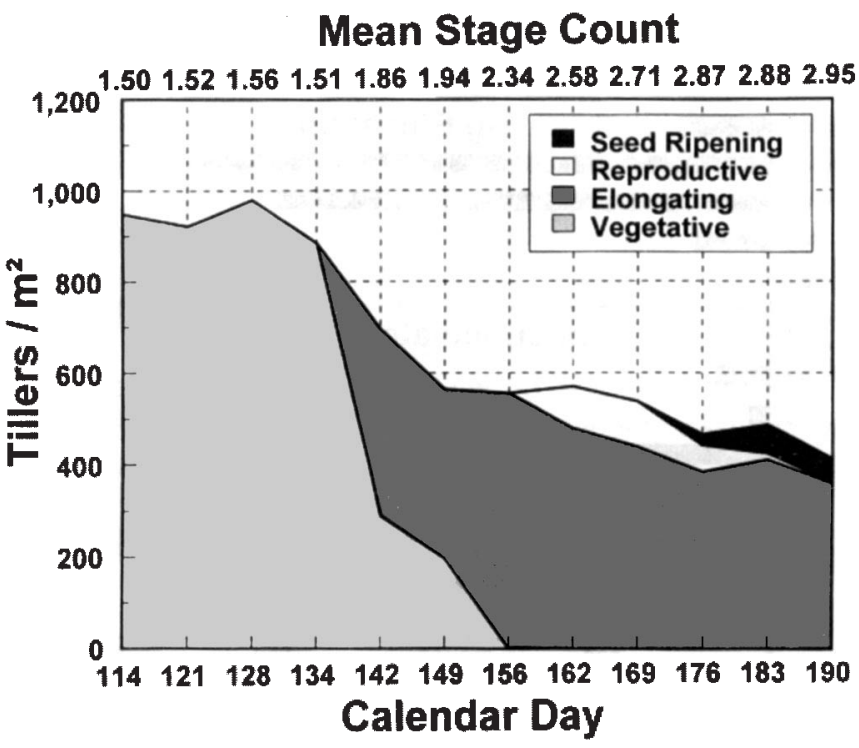

Fig. 7. Number of tillers per square meter in vegetative, elongation, reproductive, and seed ripening growth stages as a function of calendar day for intermediate wheatgrass grown near Mead, NE, during the 1991 growing season. sampling dates, all tillers were vegetative. In a period of $1 \mathrm{wk}$, however, more than half of the tillers began to elongate, and in another 3 to $4 \mathrm{wk}$, some tillers were advancing into reproductive stages. Coincident with the onset of elongation was an increase in tiller mortality that resulted in nearly a $40 \%$ decrease in the total number of tillers by Day 149. An interesting aspect of these data is the relatively small proportion of tillers that actually advanced through the reproductive to seed ripening stages. This population would have been described as fully headed based on visual observation during the reproductive and seed ripening phases when, in reality, fewer than $20 \%$ of the culms produced inflorescences.

Each of the four developmental growth phases was discernable for the tiller population described in Fig. 7. Intermediate wheatgrass, like most other temperate grasses, flowers in response to increasing daylengths. For the tiller population in Fig. 7, elongation began in midMay and continued throughout the next several weeks. By Day 156, all tillers within the population had begun to elongate and the vegetative phase ceased. The reproductive phase began 3 wk after the first tillers began to elongate and continued for about $4 \mathrm{wk}$. Seed ripening commenced midway through the reproductive phase and continued throughout the remainder of the sampling period. The overlap among growth phases represents the transition from each growth phase to the next.

Numerical indices and tiller demography can be used together to quantify and describe the developmental morphology of grass populations. In the intermediate wheatgrass example (Fig. 7), the MSC of the population never exceeded 2.95, which corresponds to a late elongation growth stage (Table 2). It is evident from these data that a MSC should not be interpreted as the actual growth stage of the population but rather as the mean representing all the growth stages present in a population. The proportion of tillers within a perennial grass population that develop through the reproductive and seed ripening growth stages has a large impact on the MSC of the population.

Variation in developmental morphology of perennial grasses arises from both genetic and environmental factors. Perennial grass cultivars are generally synthetic varieties representing a number of genotypes (Vogel and Pedersen, 1993). Consequently, there can be significant variation for plant maturity within a cultivar. Floral induction is greatly affected by environmental factors such as heat, cold, and moisture stress (Davies, 1988; Frank and Hofmann, 1994; Robson et al., 1988). In most temperate grass species, tillers must undergo a period of vernalization before floral induction occurs (Langer, 1979). Therefore, it is primarily the tillers initiated the previous fall that develop to maturity in the subsequent growing season. Any stress imposed upon the plants that results in the mortality of these tillers can result in a significant reduction in the number of tillers that become reproductive. It is not uncommon to observe differences in flowering culm densities of $100 \%$ or more from one year to the next (Roberts and Moore, 1990).

To predict the developmental morphology of perennial grass populations from one season to the next, the propor- 
tion of tillers that will become reproductive must also be predicted. The demographic approach provides a framework within which those factors that affect reproductive development of grasses may be studied and can be used in conjunction with numerical indices to describe tiller populations. From a management perspective, simply knowing the relative proportions of the primary growth stages present within a population may be adequate for making decisions based upon developmental morphology.

\section{ACKNOWLEDGMENTS}

The illustrations of the grass phytomer and grass plant in Figures 1 and 2, respectively, were drawn by Bellamy Parks-Jansen, Botany Ink, Kokomo, IN.

\section{REFERENCES}

Briske, D.D. 1991. Developmental morphology and physiology of grasses. p. 85-108. In R.K. Heitschmidt and J.W. Stuth (ed.) Grazing management: An ecological perspective. Timber Press, Portland, OR.

Burson, B.L. 1980. Warm-season grasses. p. 695-708. In W.R. Fehr and H.H. Hadley (ed.) Hybridization of crop plants. CSSA and ASA, Madison, WI.

Cao, W., and D.N. Moss. 1994. Sensitivity of winter wheat phyllochron to environmental changes. Agron. J. 86:63-66.

Casal, J.J., V.A. Deregibus, and R.A. Sánchez. 1985. Variations in tiller dynamics and morphology in Lolium multiflorum Lam. vegetative and reproductive plants as affected by differences in red/far-red irradiation. Ann. Bot. (London) 56:553-559.

Casal, J.J., R.A. Sanchez, and V.A. Deregibus. 1986. The effect of plant density on tillering: The involvement of R/FR ratio and the proportion of radiation intercepted per plant. Environ. Exp. Bot. 26:365-371.

Clark, L.G., and J.B. Fisher. 1987. Vegetative morphology of grass: Shoots and roots. p. 37-45. In K.W. Hilu et al. (ed.) Grass systematics and evolution. Smithsonian Institution Press, Washington, DC.

Clifford, H.T. 1987. Spikelet and floral morphology. p. 21-30. In K.W. Hilu et al. (ed.) Grass systematics and evolution. Smithsonian Institution Press, Washington, DC.

Davies, A. 1988. The regrowth of grass swards. p. 85-127. In M.B. Jones and A. Lazenby (ed.) The grass crop: The physiological basis of production. Chapman and Hall, New York.

Davies, A., and H. Thomas. 1983. Rates of leaf and tiller production in young spaced perennial ryegrass plants in relation to soil temperature and solar radiation. Ann. Bot. (London) 57:591-597.

Ford, H. 1982. Leaf demography and the plastochron index. Biol. J. Linn. Soc. 17:361-373.

Frank, A.B., J.D. Berdahl, and R.E. Barker. 1985. Morphological development and water use in clonal lines of four forage grasses. Agron. J. 25:339-344.

Frank, A.B., and L. Hofmann. 1994. Light quality and stem numbers in cool-season forage grasses. Crop Sci. 34:468-473.

Frank, A.B., K.H. Sedivec, and L. Hofmann. 1993. Determining grazing readiness for native and tame pastures. North Dakota State Univ. Extension Serv. Bull. R-1061, Fargo, ND.

Gould, F.W., and R.B. Shaw. 1983. Grass systematics, 2nd ed. Texas AM University Press, College Station.

Harper, J.L. 1980. Plant demography and ecological theory. Oikos $35: 244-253$.

Haun, J.R. 1973. Visual quantification of wheat development. Agron. J. 65:116-119.

Hovin, A.W. 1980. Cool-season grasses. p. 285-298. In W.R. Fehr and H.H. Hadley (ed.) Hybridization of crop plants. CSSA and ASA, Madison, WI.

Hyder, D.N. 1972. Defoliation in relation to vegetative growth. p. 303-317. In V.B. Younger and C.M. McKell (ed.) The biology and utilization of grasses. Academic Press, New York.
Jewiss, O.R. 1972. Tillering in grasses - its significance and control. J. B. Grassl. Soc. 27:65-82.

Langer, R.H.M. 1979. How grasses grow, 2nd ed. Edward Arnold (Publishers) Ltd., London.

Large, E.C. 1954. Growth stages in cereals, illustration of the Feekes scale. Plant Pathol. 3:128-129.

Marshall, C. 1987. Physiological aspects of pasture growth. p. 2946. In R.W. Snaydon (ed.) Ecosystems of the world. Vol 17B, Managed grasslands: Analytical studies. Elsevier, New York.

Moore, K.J., L.E. Moser, K.P. Vogel, S.S. Waller, B.E. Johnson and J.F. Pedersen. 1991. Describing and quantifying growth stages of perennial forage grasses. Agron. J. 83:1073-1077.

Moser, L.E., K.J. Moore, M.S. Miller, S.S. Waller, K.P. Vogel, J.R. Hendrickson, and L.A. Maddux. 1993. A quantitative system for describing the developmental morphology of grass seedling populations. p. 317-318 In Proc. 17th Int. Grassl. Congr. Vol. I. Palmerston North, New Zealand. 8-21 Feb. 1993. New Zealand Grassl. Assoc., Palmerston North.

Parsons, A.J. 1988. The effects of season and management on the growth of grass swards. p. 129-177. In M.B. Jones and A. Lazenby (ed.) The grass crop: The physiological basis of production. Chapman and Hall, New York.

Ritchie, S.W., J.J. Hanway, and G.O. Benson. 1989. How a corn plant develops. Special Rep. 48, Coop. Extension Serv., Iowa State Univ., Ames.

Roberts, C.A., and K.J. Moore. 1990. Chemical regulation of tall fescue growth and quality. Agron. J. 82:523-526.

Robson, M.J. 1982. The growth and carbon economy of selection lines of Lolium perenne cv. S23 with differing rates of dark respiration. 2. Grown as young plants from seed. Ann. Bot. (London) 49:331339.

Robson, M.J., G.J.A. Ryle, and J. Woledge. 1988. The grass plant its form and function. p. 25-83. In M.B. Jones and A. Lazenby (ed.) The grass crop: The physiological basis of production. Chapman and Hall, New York.

Sanderson, M.S. 1992. Morphological development of switchgrass and kleingrass. Agron. J. 84:415-419.

Simmons, S.R., E.A. Oelke, and P.M. Anderson. 1985. Growth and development of spring wheat. Univ. of Minnesota Agric. Extension Folder AG-FO-2547. Minneapolis, MN.

Simon, U., and B.H. Park. 1983. A descriptive scheme for stages of development in perennial forage grasses. p. 416-418. In J.A Smith and V.W. Hays (ed.) Proc. 14th Int. Grassl. Congr. Lexington, KY. 15-24 June 1981. Westview Press, Boulder, CO.

Skinner, R.H., and C.J. Nelson. 1992. Estimation of potential tiller production and site usage during tall fescue canopy development. Ann. Bot. (London) 70:493-499.

Skinner, R.H., and C.J. Nelson. 1994. Role of leaf appearance rate and the coleoptile tiller in regulating tiller production. Crop Sci. 34:71-75.

Vanderlip, R.L. 1979. How a sorghum plant develops. Coop. Extension Serv., Kansas State Univ., Manhattan.

Vogel, K.P., and J.F. Pedersen. 1993. Breeding systems for crosspollinated perennial grasses. Plant Breed. Rev. 11:251-274.

Waller, S.S., L.E. Moser, and P.E. Reece. 1985. Understanding grass growth: The key to profitable livestock production. Trabon Printing Co., Inc., Kansas City, MO.

West, C.P. 1990 . A proposed growth stage system for bermudagrass. p. 38-42. In Forages - sustaining food production and environmental quality. Proc. Am. Forage and Grassl. Conf. Blacksburg, VA. 6-9 June 1990. Am. Forage and Grassl. Council, Georgetown, TX.

White, J. 1979. The plant as a metapopulation. Annu. Rev. Ecol. Syst. 10:109-145.

White, J. 1984. Plant metamerism. p. 15-47. In R. Dirzo and J. Sarukhán (ed.) Perspectives on plant population biology. Sinauer Associates, Inc., Sunderland, MA.

Wilhelm, W.W., and G.S. McMaster. 1995. Importance of the phyllochron in studying development and growth in grasses. Crop Sci. 35: $1-3$ (this issue).

Zadoks, J.C., T.T. Chang, and C.F. Konzak. 1974. A decimal code for the growth stages of cereals. Weed Res. 14:414-421. 